\title{
Human Resource Development Practices and Job Performance of Academic Staff: A Case of Mbarara University of Science and Technology in South Western Uganda
}

\author{
Judith Arinaitwe, Enock Barigye, PhD and Basil Tibanyendera, PhD \\ Bishop Stuart University, Uganda \\ *Corresponding Email: jajudith42@gmail.com
}

\begin{abstract}
This study investigated the relationship between human resource development practices and job performance of academic staff at Mbarara University of Science and Technology. The human resource development practices in relation to job performance of academic staff were performance appraisal, training and promotion. The study used the correlational research design on a sample of 150 respondents with data collected using a questionnaire survey. Data were analysed using quantitative methods. Descriptive results revealed that performance of academic staff was high. The implementation of performance appraisal was fair (moderate). Regression results showed that training and promotion had positive and significant influence on job performance of academic staff. Nevertheless, the influence of performance appraisal on job performance of academic staff was not significant. Therefore, it was concluded that the implementation of performance appraisal was weak to have a significant influence on performance of academic staff. Training was essential for performance of academic staff in the university and promotion was a prerequisite for performance of academic staff. Hence, it was recommended that human resource director and administrators in the university should strengthen the implementation of performance appraisal, training should be prioritized to enhance performance of academic staff in the university and promotion should be given significant priority to promote performance of academic staff.
\end{abstract}

Key word: Academic Staff, Job Performance, Performance Appraisal, Promotion, Training.

\section{Introduction}

Performance of academic staff in universities is a global concern in the $21^{\text {st }}$ century (Fry, Ketteridge \& Marshall, 2008). The role of higher education academics is not limited to teaching but includes research and scholarly activities, students' research supervision, supervising internship, working with students on activities other than coursework, interacting with students outside classroom and offering community service (Mugizi, 2018; Sullivan, Mackie, Massy \& Sinha, 2012). Moreover, the major criterion of academic staff performance in the competitive environment of higher education includes publication (Hillier et al., 2019). Basing on the measure of academic staff performance in terms of publication, job performance of academic staff in the Western World is high. For instance, in the United State of America (USA), academic staff work for almost a full academic year (that is, for around nine months). USA academics conduct research, teach for an additional summer semester and take annual leave or undertake consultancy work for the remaining months of the year (Tremblay, Lalancette \& Roseveare, 2012). Academic staff of USA remain first producers of top 1 per cent most cited publications, but from the top 5 per cent category on. Academic staff from the European Union are the first producers. Lecturers in the European Union also produce almost as many top 1 per cent papers as those of the USA (Jonkers \& Sachwald, 2018). In the Western World, professorial chair is the stage of high performance with most academic staff devoting to fulfilling their research potential and mentoring young scholars (Brechelmacher, Park, Ates \& Campbell, 2015).

In Africa, low performance of academic staff is still a major challenge. Some of the professors in Africa are only local professors who are hardly known outside their institutions and are not recognised for 
the quality of their knowledge or scholarship as they hardly published in reputable publishing outlets (Simisaye, 2019). Despite the existence of a number of highly productive scholars and academic units, overall, the research performance of nationally leading African education institutions is lagging far behind similar institutions in the rest of the world (Maassen, 2015). Statistics from different universities in Africa show that research performance of most academics is poor with only South African academics reported to be the most productive. In 2012, out of the 225 papers published in a period of ten-years, academics from three Southern Africa universities contributed more than 60 per cent of all the research output in Africa (de Villiers \& Hsiao, 2017). For the universities in Uganda, only Makerere University at $2 \%$ academic publications per staff out of the total permanent staff was near the target set for South African academic staff of $5 \%$ permanent staff out of the total of permanent staff in 10 years in Africa (Cloete, Bunting, Van Schalkwyk, Amito \& Bailey, 2018).

Mbarara University of Science and Technology (MUST) whose academics are investigated is a public university that was established by an Act of Parliament in 1989. While at its inception MUST offered human medicine to undergraduate students, it has expanded to offer a number of other science programmes, postgraduate courses and particularly doctoral degrees. The expansion led to an increase in the number of students demanding a larger number of academic staff (Mugizi, 2007). To enhance performance of its academic staff, MUST has put in place human resource development practices that include performance appraisal, training and promotion. With respect to performance appraisal, the University carries out the annual performance appraisal to academic staff (Mbarara University of Science and Technology, 2018). Also, the university offers training to academic staff in different ways. For instance, the University conducts workshops and seminars, offers scholarships to academic staff and holds annual research dissemination conferences at which academics are expected to present papers and learn from other attendees. Under the Fogarty International Centre-funded program, MUST has been providing research capacity training to academic staff by which staff are given short-termfocused research training (Wakida, Maling \& Obua, 2017).
With regard to promotion, the university has different routes of promotion for academic staff that include promotion from assistant lecturer to lecturer, senior lecturer, associate professor and full professor (MUST Human Resource Manual, 2018). Nonetheless, while the academics have proved effective in the training of students by graduating many students each year, the performance of academic staff is low in the other areas such as research. For instance, research productivity of academic staff in MUST is below that of the academic staff of Makerere University at $2 \%$ publications per staff out of the total permanent staff in 10 years (Cloete et al., 2018). Therefore, this study was attracted to examine how the human resource development practices implemented by the university are related to performance of academic staff at the university. The study tested the following hypotheses:

1. There is a significant relationship between performance appraisal and job performance of academic staff.

2. There is a significant relationship between training and job performance of academic staff.

3. There is a relationship between promotion and job performance of academic staff.

\section{Literature Review}

This section presents literature on the study variables. Literature reviews involves the theoretical underpinnings and literature relating performance appraisal, training and promotion to performance of academic staff.

\section{Theoretical Underpinnings}

This study was guided by the Perceived Organizational Support (POS) Theory by Eisenberger, Huntington, Hutchinson and Sowa (1986). POS Theory postulates that employees develop global beliefs concerning the extent to which the organization values their contribution and cares about their well-being. Employees perceive their organization as supportive when they are rewarded beyond their contractual agreements (Boateng, 2014). POS Theory holds that in order to meet socio-emotional needs and to assess the benefits of increased work effort, employees form a general perception concerning the extent to which the organization values their contributions and cares about their well-being (Giorgi, Dubin \& Perez, 2016). When employees feel that they are supported by the organisation, they reciprocate it with increased level of job satisfaction, 
commitment, better performance and high work efforts. A sense of reciprocity is created when employees feel that they are supported by the organisation (Mugizi, Bakkabulindi \& Bisaso, 2015). Therefore, if the employer grants employees support in terms of good appraisal, training, promotion, pay, rank, job enrichment and organisational policies, they will reciprocate with positive attitude towards work (Nasurdin, Hemd \& Guat, 2008). POS proposes that supportive human resource development practices might enhance job performance. Therefore, POS Theory was the basis for relating human resource development practices namely performance appraisal, training and promotion with performance of academic staff.

\section{Performance Appraisal and Job Performance}

Performance appraisal (PA) is the systematic evaluation of the employees with regard to their performance on the job and their potential for development (Wonnia \& Yawson, 2015). Appraisal is an opportunity to take an overall view of work content, loads and volume, to look back at what has been achieved during the reporting period and agree on objectives for the next period (Armstrong, 2010). Appraisal provides feedback guidance in the context of an effective and more complete system of performance management which fosters employee motivation contributing to increased job performance (Selvarasu \& Sastry (2014). In their analysis of performance appraisal activities in the $21^{\text {st }}$ century in Malaysia, Ahmad and Bujang (2013) established the standard to be followed during appraisal motivated individuals or a group to a higher level of personal work behaviour. Akinbowale, Lourens and Jinabhai (2013) in a study involving employees of a bank in Nigeria found out that performance appraisal resulted in improvement in employee performance. Relatedly, in a critical review, Kaur (2013) revealed that 360 degrees appraisal gives chance to all levels of employees to give their input and contribute towards achievement of the organisation goal.

Kipchumba and Yano (2014) in a study that used employees of the Municipal Council of Nakuru in Kenya found existence of a significant relationship between the organisational use of 360 degrees appraisal tool and employee performance. However, Odhiambo (2015) conducted a study involving teachers in Kenyan secondary schools and established that appraisal policies and practices in Kenyan secondary schools were weak to significantly influence quality performance of teachers. Roberts (2003) in a critical review found out that participatory appraisal systems facilitate the discussion of employee strengths and weaknesses in a positive context, helping the employee improve his or her performance. Selvarajan and Cloninger (2012) in a study involving employees of a Mexican City established that performance appraisals from multiple sources predicted employee performance and perceived fairness and accuracy predicted higher levels of motivation to improve performance in the future. However, the studies above presented a contextual gap as they were all carried outside Ugandan universities whose performance appraisal context needed to be assessed. This gap called for this study in the context of a university in Uganda to examine the relationship between performance appraisal and job performance of academic staff.

\section{Training and Job Performance}

Training is concerned with improving of skills necessary for the achievement of organisational goals (Elnaga \& Imran, 2013). Two major training arrangements are on-the -job training and off- the job training. On-the-job training is a form of training that is normally handled by colleagues, supervisors, managers and mentors to help employees adjust to their work and to equip them with appropriate jobrelated skills. On-the-job training may consist of teaching or coaching by more experienced people or trainers at the desk or at the bench. On-the-job training may also involve individual or group assignments and projects and the use of team leaders and managers (Obisi, 2011).Off job training is a form of training which takes place in the environment other than actual workplace designed to meet the shared learning needs of a group rather than a particular individual's needs. Lectures, computer-based training, games and simulations are the common forms of off-the-job training methods (Anuar, 2011). Alipour, Salehi and Shahnavaz (2009) in a study involving top managers of organisations in Tehran province in Iran revealed that on-the-job training positively and significantly affected creativity, achieving organizational objectives and improving work quality. In a study involving local government employees of Mityana District in Uganda, Bakanye (2013) revealed existence of a positive significant correlation between employees' training programmes and employee performance.

Cheng and Ho (2001) in a study that used MBA graduates in Hong Kong reported that adequate training produced marked improvements in 
employee communication and proficiency of performances. Jagero, Komba and Mlingi (2012) analysing employee's performance of staff in courier companies in Dar es Salaam, Tanzania, reported that there was a strong relationship between on-the-job training and employee performance. Truitt (2011), using full-time salaried/exempt and hourly/ nonexempt employees from an academic institution and three businesses in the states of Maryland, Delaware, and Arizona in the USA found out that those employees who fully agreed that they received effective coaching demonstrated an increase in job proficiency. Nevertheless, the literature above also revealed contextual gaps as all the studies were conducted outside the Uganda context and the only study in this paper carried out in Uganda by Bakanye (2013) was done in a local government with completely different dynamics from those of universities. This necessitated the need to understand the training practices offered to academic staff in the universities in Uganda, hence the investigations of this study examining the relationship between training and job performance of academic staff in a university in Uganda.

\section{Promotion and Job Performance}

Promotion is the upward shift in the organisational hierarchy by an employee to a position of greater responsibility (Naveed, Ahmad \& Bushra, 2011). The movement of an employee upward in the hierarchy of the organisation, typically that leads to enhancement of responsibility and rank and an improved compensation package, is promotion (Malik, Danish \& Munir, 2012).Promotion can make a significant increase in the salary of an employee as well as in the span of authority and control (Naveed et al., 2011). Due to promotion, employees feel that they are effective contributors to the organisation and become more satisfied with their jobs increasing their job performance (Rupia, Musa, Nandi \& Odera (2012). Dar, Bashir, Ghazanfar and Abrar (2014) in a study involving employees in Islamic Banks operating in Pakistan established that development of progressive career paths was associated with higher performance. In his study, Hailesilasie (2009) used employees in Ethiopian public organizations and the findings revealed that promotion had a positive significant influence on employees' performance.

Khan, Nawaz, Aleem and Hamed (2012), using data collected from medical institutions of Punjab in Pakistan found out that facets including promotion affected the job satisfaction and performance.
Muchhal (2014) in a study involving employees in an industrial set up in India established that promotion practices correlated with employee job performance. Oduma and Were (2014) using employees of Kenyatta University in Kenya reported that promotion which gave priority to existing staff was a great morale booster and led to greater efficiency. On their part, Osibanjo, Oyewunmi and Ojo (2014) using staff from the Nigerian Banking Industry established that career development in terms of promotion and experience positively influenced organisational growth. Nonetheless, the literature above revealed contextual gaps with all the studies carried out outside Uganda. Therefore, in the context of a university in Uganda, these gaps made it imperative for this study in the context of Uganda to determine the relationship between promotion and job performance of academic staff.

\section{Research Methodology}

This section presents the methodology that was followed in carrying out this study. The section includes research design, population and sampling procedures, instruments, and data management and analysis.

\section{Research Design}

The study was based on the correlational research design. This was because the design helped to determine the presence and degree of a relationship among the study variables. With the correlational research design, the main interest was to determine whether the study variables correlated and if so, to establish the direction, magnitude, and form of the observed relationships (Ellis \& Levy, 2009). Using the correlation design, the researcher was able to determine whether a significant association existed between human resource development practices and job performance of academic staff or not.

\section{Population and Sampling Procedures}

The sample comprised 150 academic staff selected using the Table for determining sample size for a population of a given size by Krejcie and Morgan (1970). The sample was selected using stratified random sampling as seen in Table 1 (p. 45). Stratified random sampling involved dividing the sample into different subgroups namely: PhD staff, Master's Degree staff and Bachelor's Degree staff. Thereafter, the respondents were selected proportionally from the different subgroup. 


\section{Data Collection Instrument}

The study being quantitative, the data collection instrument was a self-administered questionnaire. The questionnaire was made of three sections namely section $A, B$ and $C$. The questionnaire items in section $A$ were about background characteristics of the academic staff. The items in section B and C were ordinal on job performance of academic staff (dependent variable) and human resource development practices (independent variable). The items on job performance were adapted from Abba and Mugizi (2018). The items on human resource development practices were adapted from Mugizi and Bakkabulindi (2018).The measurement scale used was a five-point Likert Scale (where $1=$ Strongly Disagree, 2 = Disagree, 3 = undecided, Agree 4 = Agree, and 5 = Strongly Agree) .

Table 1: Target Population and Sample Procedures

\begin{tabular}{lccc}
\hline Category by academic Qualification & Population & Sample Size & Sampling Method \\
\hline PhD Staff & 56 & 35 & Stratified \\
Masters' Degree Holders & 154 & 96 & Stratified \\
Bachelor's Degree Holders & 32 & 19 & Stratified \\
Total & 242 & 150 & \\
\hline
\end{tabular}

\section{Validity and Reliability}

To ensure data quality, validity and reliability tests were carried out. The validity test involved calculating of content validity index to determine the validity of the instrument. The CVI results were as follows: job performance of academic staff (0.77), performance appraisal (0.83), training (0.70), and promotion (0.75). Reliability tests for the study constructs were done using Cronbach Alpha $(\alpha)$. The Cronbach's alpha results were as follows: job performance of academic staff (0.80), performance appraisal (0.86), training (0.86), and promotion (0.83). With the CVIs and Cronbach's alphas above the benchmark of 0.70 , the questionnaire items in the instrument were considered valid and reliable.

\section{Data Management and Analysis}

Data management involved processing of the data by coding, entering them into the computer using the Statistical Package for Social Sciences (SPSS

Table 2: Background Characteristics

\begin{tabular}{|c|c|c|c|}
\hline Gender & Category & Frequency & Percent \\
\hline \multirow{7}{*}{ Age Group } & Male & 109 & 72.7 \\
\hline & Female & 41 & 27.3 \\
\hline & Total & 150 & 100.0 \\
\hline & Up to 29 years & 16 & 10.7 \\
\hline & $30-39$ years & 32 & 21.3 \\
\hline & $40-49$ years & 28 & 18.7 \\
\hline & 50 years and above & 74 & 49.3 \\
\hline \multirow{4}{*}{$\begin{array}{l}\text { Highest } \\
\text { Education }\end{array}$} & Total & 150 & 100.0 \\
\hline & Bachelor's degree & 16 & 10.7 \\
\hline & Master's degree & 92 & 61.3 \\
\hline & $\mathrm{PhD}$ & 42 & 28.0 \\
\hline \multirow{5}{*}{$\begin{array}{l}\text { Years working in the } \\
\text { University }\end{array}$} & Total & 150 & 100.0 \\
\hline & Less than 5 years & 32 & 21.3 \\
\hline & 5 - 10 years & 56 & 37.3 \\
\hline & 11 years and above & 62 & 41.3 \\
\hline & Total & 150 & 100.0 \\
\hline
\end{tabular}

24.0), summarizing them using frequency tables to identity errors and editing them to remove errors. The data were analysed using descriptive and inferential statistics. Descriptive statistics involved the means while inferential statistics included Pearson Linear correlation and regression analysis.

\section{Findings of the Study}

This part presents the finding. It begins with demographic factors and then moves into the analysis of research questions.

\section{Demographic Characteristics}

The findings in Table 2 on background characteristics of the academic staff revealed that the typical respondent was male (72.7\%), in the age category of 50 years and above (49.3\%), master's degree holders $(61.3 \%)$, and had served in the university for 11 years and above (41.3\%). 


\section{Human Resource Development Practices}

The concept of human resource development practices was conceived in terms of performance appraisal, training and promotion. The descriptive results on the same were as presented in Table 3. The results in Table 2 showed that academic staff indicated that implementation of performance appraisal in the university (mean $=3.49$ ) was moderate but provision of training (mean $=3.91$ ) was high and promotion ( mean $=3.57$ ) was also high.

Table 3: Human Resource Development Practices

\begin{tabular}{llll}
\hline Constructs & Mean & Interpretation & Rank \\
\hline Performance appraisal & 3.49 & Moderate & 3 \\
Training & 3.91 & High & 4 \\
Promotion & 3.57 & High & 4 \\
\hline
\end{tabular}

Table 4: Performance of Academic Staff

\begin{tabular}{llll}
\hline Constructs & Mean & Interpretation & Rank \\
\hline Teaching & 4.56 & High & 4 \\
Supervision & 4.50 & High & 4 \\
Research and Publication & 3.41 & Moderate & 3 \\
\hline
\end{tabular}

Table 5: Correlation between Human Resource Development Practices and Job Performance

\begin{tabular}{|c|c|c|c|c|}
\hline & Performance & Performance Appraisal & Training & Promotion \\
\hline Performance & 1 & & & \\
\hline \multirow[t]{2}{*}{ Performance Appraisal } & $0.344^{* *}$ & 1 & & \\
\hline & 0.000 & & & \\
\hline \multirow[t]{2}{*}{ Training } & $0.321^{* *}$ & $0.451^{* *}$ & 1 & \\
\hline & 0.000 & 0.000 & & \\
\hline \multirow[t]{2}{*}{ Promotion } & $0.357^{* *}$ & $0.483^{* *}$ & $0.264^{* *}$ & 1 \\
\hline & 0.000 & 0.000 & 0.001 & \\
\hline
\end{tabular}

\section{Job performance of academic staff}

The concept of job performance of academic staff was studied as a multidimensional concept including teaching, supervision and research and publication. The descriptive results on the same were as presented in Table 4.

The results in Table 4 show that academic staff indicated that their levels of teaching and supervision (mean $=4.56$ ) and (4.50) respectively were high. However, their research and publication (3.41) was moderate (average). This was probably because the means for teaching and supervision were high close to code 4 corresponding with agree (high) and the mean for research and publication was close to code 3 corresponding with undecided (moderate).

\section{Human Resource Development Practices and Performance}

To establish the extent of the relationship between human resource development practices and performance of academic staff, at a preliminary level, a correlation analysis was done. The hypotheses tested were to the effect that there is a relationship between performance appraisal and job performance of academic staff, there is a relationship between training and job performance of academic staff, and there is a relationship between promotion and job performance of academic staff. The results were as presented in Table 5.

The results in Table 4 indicate that all the components of human resource development practices namely; performance appraisal $(r=0.344$, $p=0.000<0.05)$; training $(r=0.321, p=0.000<$ $0.05)$ and promotion $(r=0.357, p=0.000<0.05)$ had moderately positive yet significant relationships with job performance of academic staff. This means that the first and third hypotheses were accepted. However, hypothesis Three was more moderately significant followed by Hypothesis One.

\section{Regression Model for Human Resource Development Practices and Job Performance}

At the confirmatory level, to establish whether human resource development practices namely; performance appraisal, training and promotion predicted job performance of academic staff, a 
regression analysis was carried out. The results were as in Table 5.

The results in Table 6 indicated that the three human resource development practices of performance appraisal, training and promotion explained $17.1 \%$ of the variation in job performance of academic staff (adjusted $\mathrm{R}^{2}=0.171$ ). However, only two human resource development practices, namely; training $(\beta=0.251, p=0.004<0.05)$ and promotion $(\beta=0.290, p=0.019<0.05)$ had $a$ significant influence on job performance of academic staff. Performance appraisal $(\beta=0.003, p$ $=0.979>0.05$ ) had an insignificant influence on job performance of academic staff. The magnitudes of the respective betas suggested that promotion had the most significant influence on job performance of academic staff. However, even the training and promotion practices weakly predicted performance of academic staff.

Table 6: Regression of Job Performance of Academic Staff on Human Resource Development Practices

\begin{tabular}{lcc}
\hline Human Resource Development Practice & $\begin{array}{c}\text { Standardized Coefficients } \\
\text { Beta }(\boldsymbol{\beta})\end{array}$ & $\begin{array}{c}\text { Significance } \\
(\mathbf{p})\end{array}$ \\
\hline Performance Appraisal & 0.003 & 0.979 \\
Training & 0.251 & 0.004 \\
Promotion & 0.290 & 0.019 \\
Adjusted $\mathrm{R}^{2}=0.171$ & & \\
$\mathrm{~F}=11.110, \mathrm{p}=0.000$ & & \\
\hline
\end{tabular}

a. Dependent Variable: Job Performance of Academic Staff

\section{Discussion of Results}

Data analysis revealed that overall job performance of academic staff was good except that research and publication were rated moderate. Therefore, with respect to teaching and supervision measures of job performance of academic staff, the findings were inconsistent with the premise on which the study was based that teaching and supervision were low because some lecturers showed less commitment to teaching (Neema-Abooki, 2016) and a number of students overstayed on the courses because of limited attention from the lecturers (Muriisa, 2015). However, the findings of the study were consistent with the premise on which this study was based that research and publication level of academic staff at the university was low because their performance was below that of the academic staff of Makerere University at $2 \%$ publications per staff out of the total of permanent staff in 10 years which was poor compared to the target of $5 \%$ set for South African universities academic staff (Cloete et al., 2018). This means that academic staff in the university gave more emphasis to teaching and supervision than research and publication.

With respect to whether there is a significant relationship between performance appraisal and job performance of academic staff, the results indicated that there was no significant relationship. This finding concurred with Odhiambo (2015) who reported that performance appraisal did not influence performance of teachers. However, the finding was contrary with the findings of most scholars. For instance, Ahmad and Bujang (2013) revealed that performance appraisal motivated individuals or a group to a higher level of personal work behaviour. Akinbowale et al. (2013) reported that performance appraisal results led to improvement in employee performance. Kaur (2013) revealed that appraisal contributed towards achievement of the organization goal. Kipchumba and Yano (2014) revealed that there was a significant relationship between the organizational use of 360 degrees appraisal tool and employee performance. Roberts (2003) reported that appraisal facilitated the discussion of employee strengths and weaknesses in a positive context helping the employee improve his or her performance. Further, Selvarajan and Cloninger (2012) indicated that appraisals from multiple sources predicted employee performance and perceived fairness and accuracy predicted higher levels of motivation to improve performance in the future. With the finding of the study inconsistent with the findings of most studies, it can be deduced that in the context of the university study, performance appraisal had challenges.

The finding that training has a significant effect on job performance of academic staff agreed with the findings of previous scholars. For instance, Alipour et al. (2009) revealed that on the job training strongly positively affected creativity, achieving organizational objectives and improves work quality. Bakanye (2013) reported a significant positive correlation between employees training programs with employee performance. Accordingly, training 
increased the employees' capacity to perform hence improved employee performance. Cheng and Ho (2001) established that adequate training produced marked improvements in employee communication and proficiency of performances. Similarly, Jagero et al. (2012) reported that there was a significant relationship between on-the-job training and employee performance. Further, Truitt (2011) indicated that those employees who fully agreed that they received effective coaching demonstrated an increase in job proficiency. With the finding of the study concurring with the findings of previous scholars, it can be inferred that training has a significant positive effect on performance of academic staff.

Further, the finding to the effect that promotion has a significant influence on job performance of academic staff confirmed the findings of previous scholars. Dar et al. (2014) revealed that development of progressive career paths was associated with higher performance. Hailesilasie (2009) reported that employee promotion had a positive significant influence on employees' performance. Khan et al. (2012) indicated that facets including promotion affected the job satisfaction and performance. Muchhal (2014) found out that promotion practices correlated with employee job performance. Oduma and Were (2014) established that promotion which gave priority to existing staff was a great morale booster and led to greater efficiency. Furthermore, Osibanjo et al. (2014) reported that career development that in terms of promotion and experience positively influenced organisational growth. With the finding of the study confirming the findings of all previous scholars, it can be surmised that promotion has a positive and significant effect of performance of academic staff.

\section{Conclusion and Recommendations}

This part presents the conclusions of the study and then gives the recommendations.

\section{Conclusions}

The discussion above led to drawing of the following conclusions on the relationship between human resource development practices and performance of academic staff. In the first place, implementation of performance appraisal influenced performance of academic staff. This was because supervisors did give emphasis to appraisal meetings, did describe performance goals during appraisal meetings, chances of promotion in the University were largely contingent on appraisal outcome and academic staff received feedback on their performance from supervisors after appraisal meetings. Secondly, training is imperative for performance of academic staff in the university. The training offered by the university provided skills needed to do a number of different jobs, the investment of the university put in training academic staff was satisfying, and the University was dedicated to their professional development. In addition, training was imperative for performance of academic staff because the training offered to the academic staff by the University taught them about the institution's values. Lastly, promotion is a prerequisite for performance of academic staff. This is especially so when there is a clear promotion policy, the policy is clearly communicated and there is provision of necessary information about routes for promotion.

\section{Recommendations}

The conclusion on performance appraisal and job performance of academic staff led to the recommendation that human resource directors and administrators in universities should strengthen the implementation of performance appraisal. This should involve giving emphasis to appraisal meetings and describing performance goals during appraisal meetings. Also, performance appraisal outcomes should be part of the factors upon which promotion is contingent and academic staff should be given sufficient feedback on their performance from supervisors after appraisal meetings. With respect to training, it should be prioritised to enhance performance of academic staff in the university. The training should provide skills needed to do a number of different jobs, not just the ordinary job of academic staff, the investment of universities put in training academic staff should be satisfying, and universities should be dedicated to professional development of academic staff. In addition, universities should avail academic staff career advancement opportunities and the training should teach academic staff the values of the institutions. Lastly, with respect to promotion, it should be given significance to promote performance of academic staff. This should be done by ensuring that there a clear policy on promotion, the policy should be clearly communicated and necessary information about employees' routes for promotion be given. 


\section{Reference}

Abba, H. D., \& Mugizi, W. (2018). Performance of academic staff in polytechnics: An analysis of performance levels in North West GeoPolitical Zone of Nigeria. Art Human Open Access Journal, 2(3), 198-203. DOI: 10.15406/ahoaj.2018.02.00056

Ahmad, R., \& Bujang, S. (2013). Issues and Challenges in the practice of Performance Appraisal Activities in the 21st Century. International Journal of Education and research, 1(4), 1-8.

Akinbowale, M. A., Jinabhai, D. C., \& Lourens, M. E. (2013). The impact of performance appraisal policy on employee performance-A case study of Guaranty Trust Bank in Nigeria. Mediterranean Journal of Social Sciences, 4(14), 677-686.

Alipour, M, Salehi, M. \& Shahnavaz, A. (2009). A study of on the job training effectiveness: Empirical evidence of Iran. International Journal of Business and Management, 4(11), 63-68.

Anuar, H. (2011). A study on the impact of training design and delivery on the training effectiveness in the context of Technology Park Malaysia (Doctoral dissertation, Universiti Utara Malaysia).Retrieved from: etd.uum.edu.my > 1.Hiswadi_Anuar.pdf

Armstrong. M. (2010). Armstrong's essential human resource management practice: A guide to people management. London, UK: Kogan Page Limited.

Bakanye, J. 2013. Impact of employee training and organisational performance: A case study of Mityana District Local Government (Master Dissertation).Uganda Martyrs University Nkozi, Nkozi, Uganda

Boateng, F. D. (2014). Perceived organizational support and police officer effectiveness testing the organizational support theory in Ghana. International Criminal Justice Review, 24(2), 134-150.doi: $10.1177 / 1057567714536907$

Brechelmacher, A., Park, E., Ates, G., \& Campbell, D. F. (2015). The rocky road to tenure-Career paths in academia. In Academic work and careers in Europe: Trends, challenges, perspectives (pp. 13-40). Springer, Cham. doi: 10.1007/978-3-319-10720-2_2

Cheng, E. W. L., \& Ho, D. C. K. (2001). The influence of job and career attitudes on learning motivation and transfer. Career Development International, 6, 20-27.

Cloete, N., Bunting, I., Van Schalkwyk, F., Amito, H., \& Bailey, T. (2018). Research Universities in Africa (p. 314). African Minds.

Dar, A.T., Bashir, M., Ghazanfar, F., \& Abrar, M. (2014). Mediating role of employee motivation in relationship to post-selection HRM practices and organizational performance. International Review of Management and Marketing, 4(3), 224-238.

De Villiers, C. J., \& Hsiao, P. C. K. (2017). A review of accounting research in internationalising journals in the South African region. South African Journal of Economic and Management Sciences, 20(1), 1-18.

Eisenberger, R., Huntington, R., Hutchison, S., \& Sowa, D. (1986). Perceived organizational support. Journal of Applied psychology, 71(3), 507. https://doi.org/10.1037/0 0219010.71.3.500

Ellis, T. J., \& Levy, Y. (2009). Towards a Guide for Novice Researchers on Research Methodology: Review and Proposed Methods. Issues in Informing Science \& Information Technology, 6, 323-336.

Elnaga, A., \& Imran, A. (2013). The effect of training on employee performance. European Journal of Business and Management, 5(4), 137-147.

Fry, H., Ketteridge, S., \& Marshall, S. [Eds.]. (2008). A handbook for teaching and learning in higher education: Enhancing academic practice. New York, USA: Routledge.

Giorgi, G., Dubin, D., \& Perez, J. F. (2016). Perceived organizational support for enhancing welfare at work: A regression tree model. Frontiers in psychology, 7 (1770), 19.https://doi.org/10.3389/fpsyg.2016.01770

Hailesilasie, G. (2009). Determinants of public employees' performance: Evidence from Ethiopian public organizations. International Journal of productivity and performance management, 58(3), 238-253.

Hillier, J. K., Saville, G., Smith, M. J., Scott, A. J., Raven, E. K., Gascoigne, J., ... \& Leckebusch, G. C. (2019). Demystifying academics to enhance university-business collaborations in environmental science. Geoscience Communication, 2(1), 1-23. https://doi.org/10.5194/gc-2-1-2019 
Jagero, N., Komba, H. V., \& Mlingi, M. N. (2012). Relationship between on the job training and employee's performance in courier companies in Dar es Salaam, Tanzania. International Journal of Humanities and Social Science, 2(22), 114120.

Jonkers, K., \& Sachwald, F. (2018). The dual impact of 'excellent' research on science and innovation: the case of Europe. Science and Public Policy, 45(2), 159174.https://doi.org/10.1093/scipol/scx071

Kaur, S. (2013). 360-degree performance AppraisalBenefits and shortcomings. International Journal of Emerging Research in Management and Technology 2(6), 83-88.

Khan, A. H., Nawaz, M. M., Aleem, M., \& Hamed, W. (2012). Impact of job satisfaction on employee performance: An empirical study of autonomous Medical Institutions of Pakistan. African Journal of Business Management, 6(7), 2697-2705.

Kipchumba, T. B., \& Yano, K. L. (2014). Perceived usefulness of the 360-degrees appraisal tool and its usage in performance in Nakuru, Kenya. Journal of Emerging Trends in Economics and Management Sciences, 5(3), 330-335.

Krejcie, R. V., \& Morgan, D. W. (1970). Determining sample size for research activities. Educational and Psychological Measurement, 30, 607-610.

Maassen, P. (2015). Research productivity at flagship African universities. World University News, Issue No: 357.

Malik, M. E., Danish, R.Q., \& Munir, Y. (2012). The impact of pay and promotion on job satisfaction: Evidence from higher education institutes of Pakistan. American Journal of economics, 2(4), 6-9.

Mbarara University of Science and Technology [MUST]. (2018). Human resource manual, 2018. Mbarara, Uganda: MUST.

Muchhal, D. S. (2014). HR practices and job performance. Journal of Humanities and Social Science, 19(4), 55-61.

Mugizi, W. (2018). The role of higher education in achieving Uganda Vision 2040. Elixir International Journal,115, 49831-49837.

Mugizi, W., Bakkabulindi, F. E., \& Bisaso, R. (2015). Framework for the study of employee commitment. Makerere Journal of Higher
Education, 7(2), 15-47. doi: http://dx.doi. org/10.4314/majohe.v7i2.2

Mugizi. W. (2007). Motivation and work attitude of academic staff in public universities in Uganda, a case of Mbarara University of Science and Technology (Masters dissertation).Makerere University, Kampala, Uganda

Muriisa, R. K. (2015). The state of doctoral education in social sciences in Uganda: experiences and challenges of doctoral training at Mbarara University of Science and Technology 2003 - 2010. Journal of Education and Practice, 6(10), 204-213.

Nasurdin, A. M., Hemd, M. A., \& Guat, L. P. (2008). Does perceived organisational support mediate the relationship between human resource management practices and organisational commitment? Asian Academy of Management Journal, 13(1), 1536.

Naveed, A., Ahmad, U., \& Bushra, F. (2011). Promotion: A predictor of job satisfaction a study of glass industry of Lahore (Pakistan). International Journal of Business and Social Science, 2(16), 301-305.

Neema-Abooki, P. (2016). Academic staff competence development as a gap in quality assurance in universities in Uganda. Makerere Journal of Higher Education, 8(2), 139-151.doi: http://dx.doi.org/10.4314/majohe.v8i2.5

Obisi, C. (2011). Employee training and development in Nigerian organisaitons: Some observations and agenda for research. Australian Journal of Business and Management Research, 1(9), 82-91.

Odhiambo, G. O. (2015). Teacher appraisal: The experiences of Kenyan secondary school teachers. Journal of Educational Administration, 43(4), 402-416.

Oduma, C., \& Were, S. (2014). Influence of career development on employee performance in the public university: A case of Kenyatta University. International Journal of Social Sciences Management and Entrepreneurship, 1(2), 1-16.

Osibanjo, A. O., Oyewunmi, A. E., \& Ojo, I. S. (2014). Career development as a determinant of organizational growth: Modelling the relationship between these constructs in the Nigerian Banking Industry. American 
International Journal of Social Sciences, 3(7), 67-76.

Roberts, G. E. (2003). Employee performance appraisal system participation: A technique that works. Public personnel management, 32(1), 89-98.

Rupia, A. S., Musa, G. H., Nandi, O. M., \& Odera, O. (2012). Perception of civil servants towards promotion on merit. American International Journal of Contemporary Research, 2(9), 4854.

Selvarajan, T. T., \& Cloninger, P. A. (2012). Can performance appraisals motivate employees to improve performance? A Mexican study. The International Journal of Human Resource Management, 23(15), 3063-3084.

Selvarasu, A., \& Sastry, S. K. (2014). A study of impact on performance appraisal on employee's engagement in an organization. International Journal of Managerial Studies and Research (IJMSR), 2(1), 10-22.

Simisaye, A. O. (2019). A study of research productivity of the academic staff in research institutes in south-west Nigeria.
Samaru Journal of Information Studies, 19(2), 75-99.

Sullivan, T. A., Mackie, C., Massy, W. F., \& Sinha, E. [Eds.]. (2012). Improving Measurement of Productivity in Higher Education. New York, USA: National Academy of Sciences.

Tremblay, K., Lalancette, D., \& Roseveare, D. (2012). Assessment of higher education learning outcomes. Feasibility study report, 1.

Truitt, D. L. (2011). The effect of training and development on employee attitude as it relates to training and work proficiency. Sage Open, 1(3), doi: $10.1177 / 2158244011433338$

Wakida, E., Maling, S., \& Obua, C. (2017). Mbarara university research training initiative: A spinoff of the medical education partnership initiative in Uganda. Advances in Medical Education and Practice, 8, 527-533. doi: 10.2147/AMEP.S138024.

Wonnia, L. K., \& Yawson, M. D. T. A. (2015). An Assessment of the Performance Appraisal System of the University for Development Studies. European Journal of Business and Management 7(17), 1-16. 